\title{
Perkembangan Konsep Demokrasi Dalam Suatu Negara Hukum Masa Kini
}

\author{
Nine Wahyu Agustina \\ IIK STRADA INDONESIA \\ Ninewahyu7@gmail.com
}

\begin{abstract}
ABSTRAK
Perkembangan Demokrasi berkembang mengikuti perkembangan bangsa dan Negara ,salah satu dari Negara demokrasi adalah Negara berdasarkan hukum. Perkembangan hukum tentunya harus mengimbangi dan dapat pilar dari kokohnya demokrasi .Masa dahulu, Masa sekarang dan Masa yang akan datang tentu ada perbedaan-perbedaan. Perbedaan tersebut juga membawa konsekuensi terhadap perkembangan demokrasi dan hukum .perkembangan hukum dindonesia di masa depan haruslah menggali nilai-nilai yang hidup dimasyarakat. Kemajemukan yang ada diindonesia merupakan sumber filosofis,sosiologis,dan yuridis bagi pengembangan hukum. Kedepan yang paling penting adalah penegakan hukum. Mengingat saat ini kritik yang paling tajam terhadap hukum selalu ditujukan kepada bobroknya penegakan hukum.
\end{abstract}

\section{Kata-Kata Kunci : konsep Demokrasi, Hukum, Masa kini}

\section{Latar Belakang}

Demokrasi merupakan nilai universal sebagai kehendak rakyat yang diekspresikan secara bebas untuk menentukan sistem ekonomi,sosial budaya dan terutama hukum,secara sederhana demokrasi digambarkan sebagai pemerintahan dari rakyat, oleh rakyat, dan untuk rakyat. pada hakikatnya demokrasi diwujudkan untuk mencapai kemakmuran.Namun masalah penegkan hukum dan demokrasi tidak pernah habishabisnya muncul di Indonesia. Akhir-akhir ini banyak terjadi,berbagai kasus berkaitan dengan masalah hukum, seperti korupsi, suap, menyuap, krinalitas tingkat tinggi, kejahatan dan lain sebagainya.dan sebuah kasus yang menyita perhatian juga muncul yaitu masalah ketidakadilan dalam hukum yang dirasakan rakyat kecil dalam hukum yang dirasakan rakyat kecil dalam kasus-kasus pencurian yang tidak seberapa nilainya, tapi pantas.

Sedangkan yang berhubungan dengan persoalan demokrasi kita melihat munculnya ketidakpuasan dalam hasil-hasil pemilihan ketidakpuasan dalam hasil-hasil pemilihan pilpres, kepala daerah, bupati. Kemudian maraknya unjuk ras mengungkapkan ketidakpuasan terhadap kinerja pemerintah, misalnya dalam kasus pemberian ketidakpuasaan dalam hasil - hasil pemilihan pilpres, kepala daerah, bupati. Kemudian 
maraknya unjuk rasa mengungkapkan ketidakpuasan terhadap kinerja pemerintah, misalnya dalam kasus pembelian fasilitas misalnya, dalam kasus pemberian fasilitas mewah bagi para pejabat dan wakil rakyat yang dinilai tidak mencerminkan kepekaan social,dan dalam kasus Bank Century yang sampai saat ini masih kurang jelas dari persoalan penegakan hukum dan demokrasi ini tampak dengan jelas potensi untuk melahirkan ketidakstabilan dalam masyarakat itulah sebabnya, masalah pembangunan/perkembangan demokrasi hukum sangat penting perannya. Mengenai kehidupan demokrasi yang dicerminkan dalam bentuk kekecewaan masyarakat dalam pemilu, pilpres, pilkada, pilbub memang masih terdapat berbagai kelemahan dalam teknis pelaksanaan. Semua itu harus selalu kita evaluasi dan diambil sebagai pengalaman untuk penyelenggaraan pesta demokrasi di masa yang akan datang hingga lebih sempurna dan memuaskan masyarakat.

\section{Rumusan Masalah}

Berdasarkan pada uraian latar belakang masalah tersebut di atas, maka dapat dirumuskan permasalahan sebagai Berikut :

1. Bagaimana hukum dan demokrasi membangun bangsa dan relevansi kepemimpinan indoneisa?

2. Bagaimana meningkatkan martabat manusia dan kesejahteraan Negara dan membudayakan kritik untuk mencapai kemajuan?

\section{Tinjaun Pustaka}

Negara Hukum adalah Negara yang sistem penyelenggaraan Negara didasarkan pada suatu aturan hukum. Hukum merupakan sebuah kata yang masih abstrak, maka sebagai perwujudannya dengan dikodifikasikannya suatu hukum kedalam tulisan yang disebut peraturan perundang-undangan. Peraturan perundang-undang disetiap suatu Negara memiliki hakekat masing-masing. Tepatlah theory yang dipelopori oleh Hans Kalsen ,bahwa hukum memiliki turunannya di dalam peraturan perundang-undangan ,peraturan tertinggi didalam suatu Negara biasa disebut konstitusi.

Demokrasi dalam pengertian budaya dan sikap hidup prilaku yang menujukkan komitmen dan pengharggan pada nilai-nilai kemanusian. Sebuah sikap yang menafikan arogansi dan kesombongan, sebaliknya menghargai martabat manusia sebagai mahluk yang dimulakan Allah pencipta semesta ini.Dengan demikian dalam demokrasi sebagai sistem budaya,manusia dinilai sama derajadnya. Tidak ada pebedaan dinilai sama derajadnya. Tidak ada pebedaan yang menyebabkan manusia ditempatkan sebagai memiliki derajat rendah dan tinggi. Dalam demokrasi, seseorang dinilai tinggi keberadaannya bila ia mampu menghormati manusia sebagai manusia yang sama. 
Negara Hukum demokrasi, memiliki dua kedaulatan yang bersintesis dan diintegrasikan menjadi satu kekuasaan tersebut adalah kekuasaan hukum dan kekuasaan rakyat. Kekuatan hukum artinya kedaulatan rakyat. Kekuasaan hukum artinya kedaulatan didasarkan pada hukum dimana perundangan menjadi dasar penyelenggaraan Negara. Sedangkan kekuasaan rakyat artinya kedaulatan ada pada rakyat, dimana rakyat memengang kendali penuh atas Negara,bias ditarik kesimpulan bahwa rakyat merupakan pemegang kekuasaan tertinggi dalam suatu sistem pemerintahan atau dalam suatu Negara, dimana masing-masing dari mereka memiliki hak dalam memperoleh kesempatan serta hak yang sama dalam upaya mengatur kebijakan publik.

\section{Pembahasan}

Diberbagai media online para penulis banyak yang menggambarkan kondisi hukum Indonesia saat ini.Mereka menyatakan bahwa kondisi hukum di Indonesia saat ini lebih sering mendapat kritik dari pada pujian. Berbagai kritik diarahkan baik yang berkaitan dengan penegakan hukum, kesadaran hukum,kualitas hukum,ketidakjelaskan berbagai hukum yang berkaitan denga proses hukum dan juga lemahnya penerapan hukum di dalam praktek. kondisi hukum yang demikian buruknya itu akan berpengaruh terhadap kekautan dan kemajuan demokrasi di Indonesia. Khususnya dalam penegakan hukum,persiden SBY pun mengakui lemahnya penegakan hukum tersebut akan mempengaruhi demokrasi di Indonesia.menurut SBY ada tiga pilar demokrasi di Indonesia yaitu : adanya kebebasan, adanya perlindungan terhadap hak asasi manusia dan penegakan hukum. Menurut SBY dari tiga pilar tersebut penegakan hukum di Indonesia belum maksimal. Banyak Ungkapan - ungkapan masyarakat yang mengambarkan buruknya penegakan hukum,khususnya dengan penegakan hukum,kebanyakan masyarakat menyatakan hukum dapat dibeli. Bahkan ada plesetan terhadap kepanjangan dari KHUP yang arti sebenarnya adalah Kitab. Undang-Undang Hukum pidana di plesetkan menjadi kasih uang Habis perkara. Ungkapan tersebut bahwa hukum hanya mampu menghukum kepada orang-orang bawah atau atau orang-orang kecil sedangkan terhadap orang-orang yang kaya, berkuasa hukum tidak mampu memfungsikan dirinya. Dimana masyarakat kecil yang menjadi tersangka akan dihukum pidanan penjara dan harus menajalani penjara.

Namun masyarakat yang memiliki kuasa akan dihukum percobaan dengan tidak menjalani pidana penjara. Berbagai argumentasi atau pertimbangan hukum disampaikan oleh hakim untuk memberi pembenaran atas putusannya. Memang secara procedural hal tersebut benar adanya. Ketua putusan tersebut benar sesuai dengan prosedur hukum namun bagaimana dengan sisi rasa keadilan di dalam masyarakat. Jadi apabila hukumnya rusak atau lemah maka demokrasi dapat rusak dan lemah.salah satu masalah dalam hukum di Indonesia adalah dari segi norma. Sejak reformasi tahun 1998 sampai sekarang, Indonesia telah melakukan empat kali amandemen terhadap konstitusi Indonesia yaitu UUD 1945. Tentunya norma undangundang yang tidak sesuai wajib diubah guna menyesuaikan UUD 1945 hasil amandemen ke 4. Sejak adanya amandemen UUD 1945 telah banyak perubahan dan atau pembentukan peraturan- 
peraturan yang baru, yang dibuat oleh anggota dewan bersama pemerintah, akan tetapi normanorma yang baru tersebut belum secara cepat tersosialisasikan sehingga pelaksanaannya banyak mengalami kendala bahkan ada yang gagal Selain hal tersebut di atas, terhadap norma perundang-undangan yang baru juga banyak yang diajukan judisial review ke Makamah Konstitusi . Kondisi Hukum Indonesia Masa Depan, Tujuan hukum secara umum adalah :

- untuk menciptakan kesejahteraan masyarakat. Hal ini sesuai dengan fungsi hukum Tool of social engineering bahwa hukum digunakan untuk merekayasa kehidupan sosial demi terwujudnya kesejahteraan masyarakat. Demokrasi substansial adalah demokrasi yang mengandung nilai. Demokrasi sebagai nilai dibangun di atas tiga pilar.

- Adanya perlindungan terhadap hak asasi manusia dan yang ke 3 adalah penegakan hukum. Oleh karenanya didalam membuat regulasi maka harus mengandung pilar demokrasi diantaranya adalah kebebaan, kemajemukan, perlindungan hak asasi manusia dan penegakan hukum.

- Adanya perkembangan kehidupan masyarakat membawa konsekuensi terhadap perkembangan hukum. Idealnya hukum mampu untuk mengatur semua perubahan tersebut di atas, namun kenyataanya bahwa hukum selalu kalah melangkah dengan perkembangan jaman. Terutama pada hukum positif. Negara yang menganut sivil law system atau eropa continental atau hukum tertulis biasanya perkembangan hukum akan tertatih-tatih mengikuti perkembangan kehidupan masyarakat.

Untuk itu kedepan hukum yang baik dan dapat dikembangkan adalah hukum progresif. Hukum progresif dicetuskan dengan latar belakang keprihatinan terhadap realitas penegakan hukum yang carut marut, penegak hukum yang tersandera oleh tuntutan terpenuhinnya keadilan formal. Menurut Mafud MD, Bagi hukum Progresif, yang dikatakan hukum yang benar itu bukanlah bunyi undang-undang semata-mata, melainkan denyut kehidupan masyarakat. Dari uraian di atas dalam perkembangan hukum dimasa depan, khususnya dibidang penegakan hukum perlu dikembangkanya hukum progresif.Namun apa bila undang-undang tidak dapat memberikan rasa keadilan penegak hukum dapat mengali nilai-nilai yang hidup di dalam masyarakat. Untuk itu penegakan hukum juga harus mengikuti perkembangan demokrasi. Perkembangan hukum di masa depan tidak boleh jauh dari nilai-nilai yang berkembang di dalam masyarakat. Memang sangat baik mengadopsi system hukum Negara lain namun secara substansial hukum di Indonesia harus digali dari nilai-nilai pancasila atau kehidupan bangsa Indonesia sendiri agar menciptakan persatuan dan kesatuan bangsa.

Untuk itu hukum adat di masa depan harus dikembangkan dan dilestarikan. Demikian juga dalam hal pengaturan tingkah laku antara larangan, dan perbolehan hukum adat lebih dipatuhi oleh masyarakat adat .Demokrasi yang baik/sehat menciptakan persatuan dan kesatuan di suatu Negara tersebut. Ibis society ibis ius dimana ada masyarakat disitu ada hukum, artinya 
bahwa hukum tumbuh dan berkembang seiring tumbuhnya masyarakat. Masalah hukum saat ini yang paling banyak mendapat kritik adalah masalah penegakan hukum. untuk itu membangun hukum masa depan harus membagun penegakan hukum. Hukum progresif telah memberikan satu konsep didalam penegakan hukum.

\section{Kesimpulan}

Diberbagai media online para penulis banyak yang menggambarkan kondisi hukum Indonesia saat ini.Mereka menyatakan bahwa kondisi hukum di Indonesia saat ini lebih sering mendapat kritik dari pada pujian. Berbagai argumentasi atau pertimbangan hukum disampaikan oleh hakim untuk memberi pembenaran atas putusannya. Ketua putusan tersebut benar sesuai dengan prosedur hukum namun bagaimana dengan sisi rasa keadilan di dalam masyarakat. Hal ini sesuai dengan fungsi hukum Tool of social engineering bahwa hukum digunakan untuk merekayasa kehidupan sosial demi terwujudnya kesejahteraan masyarakat. Demokrasi sebagai nilai dibangun di atas tiga pilar.

\section{Daftar Pustaka}

Siyoto, S., \& Sodik, M. A. (2015). Dasar metodologi penelitian. Literasi Media Publishing.

https://scholar.google.co.id/scholar?hl=id\&as_sdt=0\%2C5\&q=muhammad+ali+sodik\&oq=\#d=g s_qabs\&u=\%23p\%3DjGF7Wz2n5JkJ

Kurniawan, G. (2015). Kebebasan Sebagai Hakekat Demokrasi. INOVATIFI Jurnal Ilmu Hukum, $8(1$

https://scholar.google.co.id/scholar?hl=id\&as_sdt=0\%2C5\&q=perkembangan+demokrasi+saat+ ini\&oq=\#d=gs_qabs\&u=\%23p\%3DzVYwrQaraGoJ

Palguna, I. D. G. (2010). Constitutional Question: Latar Belakang dan Praktik Di Negara Lain Serta Kemungkinan Penerapannya Di Indonesia. Jurnal Hukum lus Quia lustum, 17(1), 1-20.

https://scholar.google.co.id/scholar?hl=id\&as_sdt=0\%2C5\&q=latar+belakang+demokrasi+huku $\underline{m} \& b t n G=\# d=g s \_q a b s \& u=\% 23 p \% 3 D I D U c 3 e Z a 7 y g J$

Agustina, N. W. (2021). Arti Pentingnya Toleransi Antar Agama Dalam Persatuan Dan kesatuan Bangsa Indonesia.

https://scholar.google.com/scholar?hl=id\&as_sdt=0\%2C5\&q=Arti+Pentingnya+Toleransi+Antar +Agama+Dalam+Persatuan+Dan+kesatuan+Bangsa+Indonesia\&btnG=\#d=gs_qabs\&u=\%23p\%3 De-nglyusaVQJ

Agustina, N. W. (2021). Hak untuk memperoleh pelayanan kesehatan jiwa.

https://scholar.google.com/scholar?hl=id\&as_sdt=0\%2C5\&q=Hak+untuk+memperoleh+pelayan an+kesehatan+jiwa\&btnG=\#d=gs_qabs\&u=\%23p\%3DgrJ8_TRHqYYJ 